\title{
Biosynthesis and characterization of Gynocardia odorata R. Br. mediated silver nanoparticles and evaluation of its antimicrobial activity
}

\author{
Dipjyoti Kalita ${ }^{1 *}$, Himanshu Rajbongshi ${ }^{2}$, Nilakshee Devi ${ }^{1}$, Mohan Chandra Kalita ${ }^{3}$ \& Sunandan \\ Baruah $^{4}$ \\ ${ }^{1}$ Department of Botany, Gauhati University, Guwahati 781 014, India \\ ${ }^{2}$ Department of Physics, Bahona College, Jorhat 785 001, India \\ ${ }^{3}$ Department of Biotechnology, Gauhati University, Guwahati 781 014, India \\ ${ }^{4}$ Faculty of Engineering, Assam Down Town University, Panikhaiti, Guwahati 781 068, India \\ *Email: dipkalita3191@gmail.com
}

\section{ARTICLE HISTORY}

Received: 19 April 2021

Accepted: 26 June 2021

Available online: 19 August 2021

KEYWORDS

Biosynthesis

Silver nanoparticles

Gynocardia odorata

Antibacterial activity

\section{ABSTRACT}

The present study was designed to synthesize Silver Nanoparticles (Ag-NPs) in aqueous medium using leaf extract of Gynocardia odorata R. Br. (Achariaceae). The synthesized Ag-NPs were characterized using different technique such as UV-Visible Spectroscopy, X-Ray Diffraction (XRD) Spectroscopy, Fourier Transform Infrared Spectroscopy (FTIR) and Transmission Electron Microscopy (TEM). The reduction of $\mathrm{Ag}$ ions to initiate nucleation and subsequent Ostwald Ripening to form nanoparticles was made possible by the presence of various antioxidants in the leaves of Gynocardia odorata. These antioxidants served both as reducing and capping agents. The synthesized Ag-NPs were found to be polydispersed in nature and spherical in shape. With the Surface Plasmon Resonance (SPR) optical absorption band peak at $\sim 40 \mathrm{~nm}$ was observed using UV-Vis spectrophotometer. FTIR confirmed the presence of methoxy and allyl groups in the synthesized Ag-NPs and nearly 15-45 nm diameter spherical shaped NPs was validated using TEM. The synthesized Ag-NPs were stable for a long period (more than six months) and showed good antibacterial activity against both gram positive and gram negative bacterial strains and the effect was higher as compared to the normal aqueous extract.

\section{Introduction}

Nanotechnology is a disrupting technology that has triggered interest in a number of domains including medicine, agriculture, food, packaging etc. This field of science has been receiving a lot of attention in the past years. It has provided a platform to understand how physiognomy of nanoparticles (NPs) can dramatically change the flavour, appearance, sense and aroma of foodstuffs with an increase in nutrition. Nanotechnology merged with other pre-existing technologies is creating innovations which ensure safety and security (1). The biosynthetic methods for the synthesis of NPs have gained considerable attention in the past decade as there is no requirement of synthetic chemicals for the production protocols. The synthesis of nanoparticles by chemical route has the downside that colloidal solutions are tainted with different by-products of chemical reactions (2). The chemical treatment method of NPs has contamination issues with various reaction by-products. Considerable efforts have already been put to develop environment friendly protocols for the synthesis of nanoparticles. A number of works has been done to develop microorganisms for the manufacture of metal nanoparticles (3-12). One worth mentioning downside of the production of nanoparticles using such microorganisms is the long duration of synthesis process, ranging from 24 to $120 \mathrm{hrs}$ (13).

In order to limit this problem, very recently, the attention has been shifted to the application of certain plants or plant parts for nano-synthesis or simply nano-biosynthesis $(14,15)$. Now-a-days, the use of "green" chemistry laws in nanotechnology and materials science increases the use of nanomaterials due to genuinely significant advancement (16). The application of this eco-friendly synthesis procedure has developed rapidly as compared to the microorganism assisted ones as raw materials are easily available and does not involve maintenance of highly aseptic conditions (17-20). Development and documentation of these experimental processes for the synthesis of NPs is considered as an important

(c) Kalita et al. (2021). This is an open-access article distributed under the terms of the Creative Commons Attribution License, which permits unrestricted use, distribution and reproduction in any medium, provided the original author and source are credited (https://creativecommons.org/licenses/by/4.0/). 
contribution for nanotechnology research. Ag-NPs have been widely used in numerous applications over the last few years, such as biomedicine, biosensor and catalysis $(21,22)$. The green synthesis of Ag-NPs and its application against different bacteria (23), fungi $(24,25)$, algae (26), plant extracts (27-34) as well as biological compounds $(16,30)$ have been reported.

Gynocardia odorata is one of the important tree species under family Achariaceae (earlier in Flacourtiaceae) is also known as Chaulmoogra (3537). It grows in the dense tropical and temperate forest and also in secondary forest margin $(38,39)$. It is cultivated in some parts of Jaintia Hill, Meghalaya (40). It is an East Indian tree which is fairly common in the evergreen forests throughout the North Eastern province of India and is indigenous to this region $(41,42)$. This monotypic genus has been reported to be used in various folk medicines and also in other community practices (43-48). Initially, it was believed that the seeds of Gynocardia odorata was the source of Chaulmoogra oil, but Sir David Prain in 1901 researched chaulmoogra seeds and concluded that they were from Taraktogenos kurzii. From then onwards, Gynocardia odorata became "False Chaulmoogra" (49). The seeds are grayish, smooth, irregularly ovoid, compressed, angular and possess a peculiar nauseous aroma $(50,51)$. The plant has long been applied for stiff joints, sprains, rheumatism, neuralgia and both internally and externally in secondary syphilis, scrofula, phthisis, eczema, neuralgia, lupus, psoriasis and other inflammatory skin diseases $(47,52)$.

\section{Materials and Methods}

\section{Collection and Preparation of plant extract}

Fresh leaves of Gynocardia odorata R. Br. were collected around Kamrup (M) district of Assam. They were washed thoroughly with tap water and then rinsed with distilled water to remove dust particles and were shade dried for $72 \mathrm{hrs}$ at room temperature. The air dried leaves were ground to coarse powder using a blender. Five gram of the dried leaf powder was taken in a beaker and mixed with $100 \mathrm{ml}$ of distilled water. This mixture was kept at $40{ }^{\circ} \mathrm{C}$ for $30 \mathrm{~min}$. in a water bath and cooled to room temperature and filtered through Whatman filter paper No 1. Finally, the extract was refrigerated and kept for further experiments.

\section{Synthesis of Ag-Nps}

$1 \mathrm{ml}$ of the leaf aqueous extract was taken and added $9 \mathrm{ml}$ of $1 \mathrm{mM}$ solution of $\mathrm{AgNO}_{3}$ in a glass vial. The reaction was performed in dark at room temperature and kept overnight to minimize photo-activation of $\mathrm{AgNO}_{3}$. The aqueous leaf extract of Gynocardia odorata and $\mathrm{AgNO}_{3}$ solution were used as control. The colour shift of the solution from green to brown indicated the formation of Ag-NPs. After the desired reaction period, the dispersion containing Ag-NPs was centrifuged at $10000 \mathrm{rpm}$ for $15 \mathrm{~min}$. The pellet was collected and re-dispersed in distilled water to remove organic materials and debris. The whole process was repeated thrice to ensure a better separation of the free entities from the Ag-NPs. The purified pellets were then kept into petri-plates and left on the oven for drying at $60{ }^{\circ} \mathrm{C}$ for $24 \mathrm{hrs}$. The dried Ag-NPs were considered as final product which was scrapped out for further study and characterization.

\section{Characterization of Ag-Nps}

Characterization of the synthesized Ag-NPs was carried out using the following techniques:

\section{UV-Visible Spectroscopy}

The formation of the pure Ag-NPs (Brown coloured solution) was observed under UV-Visible spectrophotometer (Hitachi U2900 and Elico SL159) and the absorbance was measured in between 300 $\mathrm{nm}$ and $800 \mathrm{~nm}$. The UV-Visible spectra of the leaf aqueous extract and $\mathrm{AgNO}_{3}$ solution were also recorded using distilled water as blank.

\section{X-Ray Diffraction (XRD)}

The crystalline properties of Ag powder were analyzed by using X-Ray Diffractometer (Philips X'Pert Pro powder X-ray Diffractometer) with CuKa radiation ( $\lambda=1.5406 \AA$ ) to know the intensity of formation of different sized Ag-NPs.

\section{Fourier Transform Infrared Spectroscopy (FTIR)}

FTIR spectra of the leaf extract and Ag-NPs samples were obtained using a FTIR spectroscope (Hitachi Ltd., Tokyo, Japan). The FTIR analysis was performed using $\mathrm{KBr}$ pellets and recorded in the range of 400 $4000 \mathrm{~cm}^{-1}$. The various modes of vibrations were identified and assigned to determine the different functional groups present in the samples.

\section{Scanning Electron Microscopy (SEM) and Energy Dispersive X-Ray Analyzer (EDX)}

SEM and EDX were performed to study the surface morphologies of synthesized Ag-NPs and the elemental analysis (Model no: ZEISS Sigma 3000).

\section{High Resolution Transmission Electron Microscopy(HRTEM)}

HRTEM observations were made to determine the size of NPs using TECNAI G2 20 S-TWIN TEM software, operated at $200 \mathrm{kV}$. A drop of Ag-NPs was placed on an amorphous carbon coated copper grid and allowed to stand for $2 \mathrm{~min}$. The excess solvent was removed using a blotting paper and the grid was allowed to dry at room temperature.

\section{Antibacterial Activity}

To evaluate the bactericidal action of the synthesized Ag-NPs, in vitro antibacterial activity was performed using Disc Diffusion Method against two gram positive bacteria viz. Staphylococcus aureus (MTCC 96) and Bacillus subtilis (MTCC 441) and two gram negative bacteria Enterobacter aerogenes (MTCC 111) and Escherichia coli (MTCC 739). The strains were obtained from IMTECH Chandigarh and were maintained in IBH, Department of Biotechnology, Gauhati University. Mackonkey broth (HiMedia) medium was used to sub-culture the bacteria and were incubated at $37^{\circ} \mathrm{C}$ for $24 \mathrm{hrs}$. The sterilized petri 
plates containing $15 \mathrm{ml}$ of molten media of Mueller Hinton Agar (MHA) were prepared and allowed to solidify. The dried plates were inoculated with test strains uniformly over the surface. A sterile $5 \mathrm{~mm}$ Whatman Filter Paper No. 1 saturated with appropriate solutions of Ag-NPs (positive control) and a known antibiotic (Ampicillin) was placed on the surfaces of the inoculums. Approximately $50 \mu \mathrm{l}$ of the solutions and antibiotic were loaded on the discs and were permitted to diffuse for $5 \mathrm{~min}$. Finally, the plates were incubated at $37{ }^{0} \mathrm{C}$ for $24 \mathrm{hrs}$. The antibacterial activity was measured based on the inhibition zone around the disc impregnated with AgNPs. The bactericidal activity was evaluated by the size of clear zone. Greater the zone of inhibition shows greater bactericidal activity. The whole experiment was performed in triplicate to avoid biasness.

\section{Results and Discussion}

\section{UV-Vis spectral studies}

Aqueous leaf extract of Gynocardia odorata leaf was mixed with $\mathrm{AgNO}_{3}$ at $1 \mathrm{mM}$ showed a change in colour from light yellow to dark brown (Fig. 1) which was due to the Surface Plasmon Resonance (SPR) on the surface of Ag-NPs. Fig. 1 represents different concentrations of synthesized Ag-NPs with respect to the shift in colour change. The control solutions i.e. aqueous Gynocardia odorata extract and $\mathrm{AgNO}_{3}$ along with blank i.e. double distilled water (DI) neither developed the characteristic yellow colour nor did they display the characteristic peaks between $300 \mathrm{~nm}$ and $800 \mathrm{~nm}$.

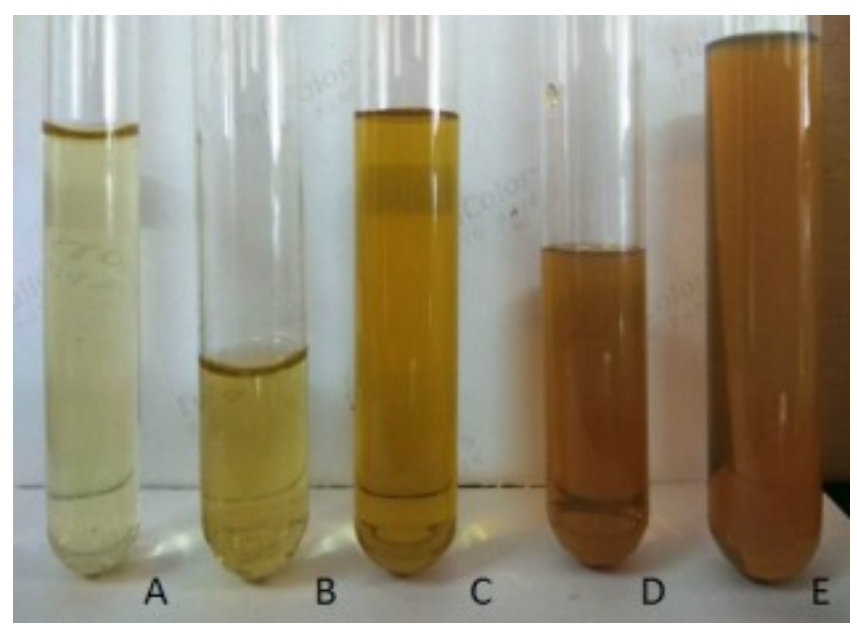

Fig. 1. Synthesized Ag-Nps.

$$
\text { G. odorata }(\mathrm{GO})
$$

A. $\mathrm{AgNO}_{3}$, B. $2.5 \% \mathrm{GO}+\mathrm{AgNO}_{3}$ C. $5 \% \mathrm{GO}+\mathrm{AgNO}_{3}$, D. $7.5 \% \mathrm{GO}+\mathrm{AgNO}_{3}$, E. $10 \% \mathrm{GO}+\mathrm{AgNO}_{3}$.

Fig. 2 indicated the abiotic reduction of synthesized Ag-NPs on varying concentrations (2.5\% $\mathrm{GO}+\mathrm{AgNO}_{3}, \quad 5 \% \quad \mathrm{GO}+\mathrm{AgNO}_{3}, \quad 7.5 \% \quad \mathrm{GO}+\mathrm{AgNO}_{3}, \quad 10 \%$ $\mathrm{GO}+\mathrm{AgNO}_{3}$ respectively). The figure shows that as the concentration of $\mathrm{AgNO}_{3}$ increased, the absorption peak shifted towards right (from light yellow to brown coloured solution) in between $300 \mathrm{~nm}$ and 800 $\mathrm{nm}$ wave length. The reduction of Ag-NPs in the aqueous solution of $\mathrm{Ag}$ complex during the reaction with the leaf extract of Gynocardia odorata was confirmed by UV visible spectra. Sharp peak in the absorption spectrum of Ag NPs at $430 \mathrm{~nm}$ after $24 \mathrm{hrs}$ indicated that the particles were formed monodispersed. The Surface Plasmon peak for Ag NPs became distinct with an increasing concentration of $\mathrm{AgNO}_{3}$. In order to achieve controlled growth and definite particle size, $10 \% \quad \mathrm{GO}+\mathrm{AgNO}_{3}$ aqueous Gynocardia odorata (GO) was used for further antibacterial study.

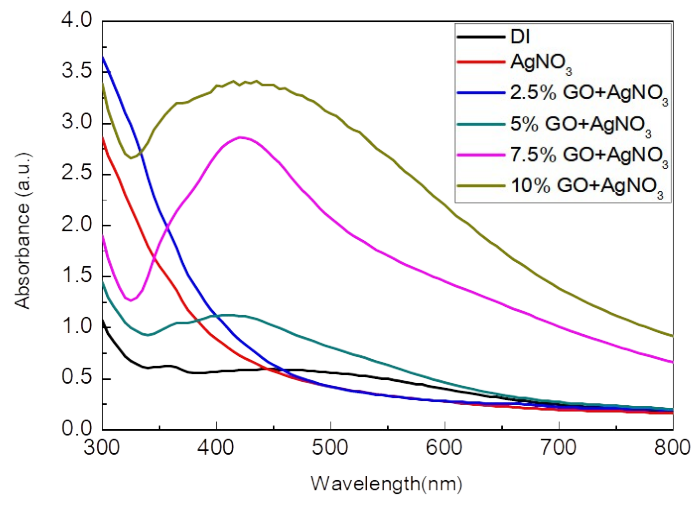

Fig. 2. UV- Vis absorption spectra of synthesized Ag-Nps.

\section{$X$-ray Diffraction}

XRD was carried out for phase characteristics analysis by observing peak shifting patterns of synthesized Ag NPs (Fig. 3). The XRD pattern displays four diffraction peaks viz. 111, 200, 220 and 222 corresponding to $2 \Theta=38.9^{\circ}, 44.92^{\circ}, 63.74^{\circ}$ and $77.24^{\circ}$ respectively (JCPDS File No.04-0783). It showed that the intensity of 111 peak was more sharp for all four concentrations of Ag-NPs [(a) 2.5\%, (b) $5 \%$, (c) $7.5 \%$, and (d) 10\%] than the remaining three peaks. This

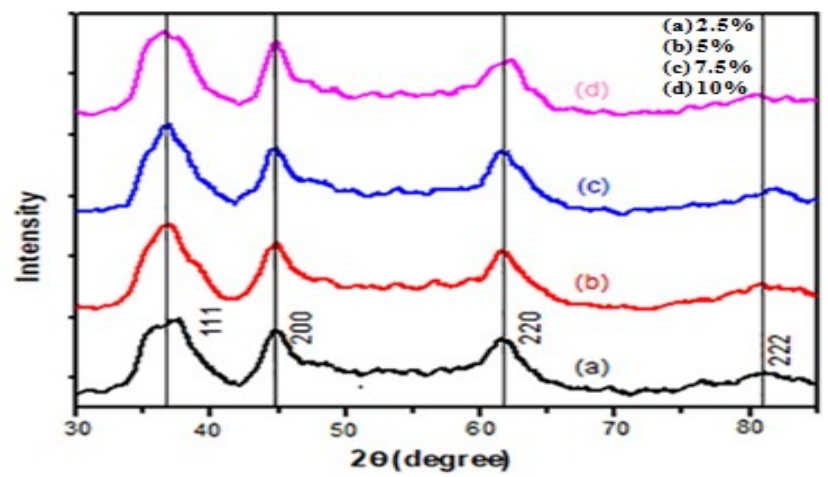

Fig. 3. XRD patterns of synthesized Ag-Nps.

indicated slight anisotropy along the 111 direction perpendicular to the $2 \theta$ plane. Similarly, XRD patterns of other concentrations of Ag-NPs samples showed the existence of four well-defined diffraction peaks viz. 111, 200, 220 and 222 almost at the same angles as it was obtained for Ag-NPs (2.5\%). The peak due to 111 plane for the three Ag-NPs samples (5\% GO, $7.5 \%$ GO and $10 \% \mathrm{GO}$ ) compared to that for $2.5 \%$ GO sample was found to be shifted towards lower angle. This shift may be due to the formation of small sized Ag-NPs with the increase in the concentration of Gynocardia odorata sample solution. Thus, increase in the concentration may result into sharpness of peak intensity. 


\section{Fourier Transform Infrared Spectroscopy}

Fourier Transform Infrared Spectroscopy spectrum (Fig. 4) explains the interaction of Ag-NPs with biomolecules present in Gynocardia odorata leaf. The broadband at $1680-1710 \mathrm{~cm}^{-1} \mathrm{can}$ be attributed to the stretching vibrations of strong $\mathrm{C}=\mathrm{O}$ stretching of conjugated acid, while the absorption band at 2830$2695 \mathrm{~cm}^{-1}$ to medium C-H stretching of Aldehyde group. A major absorption band is observed at 3200$3550 \mathrm{~cm}^{-1}$ due to the strong $\mathrm{O}=\mathrm{H}$ stretching vibration for alcohol group. The FTIR results confirm the presence of $\mathrm{C}=\mathrm{O}, \mathrm{C}-\mathrm{H}$, and $\mathrm{O}=\mathrm{H}$ groups, which indicates that the plant extract contains conjugated acid, aldehyde and alcohol groups. Thus, the FTIR study reveals the multi-functionality of the aqueous extract of Gynocardia odorata that allow reduction and stabilization to occur simultaneously during nanoparticle (NPs) synthesis.

\section{Scanning Electron Microscopy}

Typical SEM images (Fig. 5) of the synthesized Ag-NPs

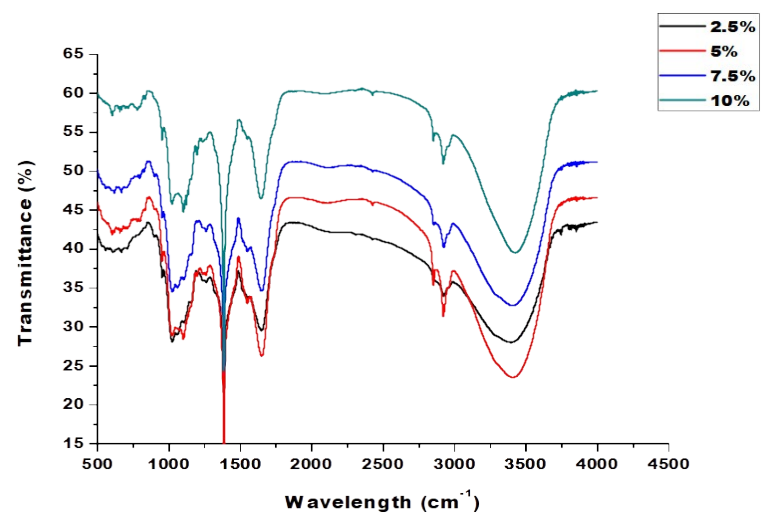

Fig. 4. FTIR spectra of synthesized Ag-Nps.

using $10 \%$ aqueous Gynocardia odorata and $10 \mathrm{mM}$ $\mathrm{AgNO}_{3}$ at above mentioned conditions are presented in Fig. 5 using different magnification scale. It was observed that the surface morphology of Ag-NPs biosynthesized from Gynocardia odorata solution clearly showed that they were in irregular shapes. Here, some smaller particles (black circles) of spherical and irregular shapes were also seen with different sizes. A few traces of Ag-NPs microstructures (white circles) probably due to the aggregation of NPs which might be induced by the evaporation of solvent during sample preparation which resulted into particle agglomeration with variation in particle size.

The SEM-EDAX (Fig. 6) spectrum shows a single peak for Ag, indicating that the synthesized Ag-NPs were free from impurity. The elemental composition of powdered samples was determined using SEM equipped with an EDAX detector. The energy dispersive X-ray analysis (EDAX) shown in Fig. 6 revealed the strong signal in the $\mathrm{Ag}$ region and confirmed the formation of Ag-NPs. Spectral signals were also observed for $\mathrm{Mg}, \mathrm{Cr}, \mathrm{As}, \mathrm{Si}, \mathrm{Ca}, \mathrm{K}$ and $\mathrm{C}$ indicating that the extracellular organic moieties from Gynocardia odorata were adsorbed on the surface or in the vicinity of the metallic NPs. Au
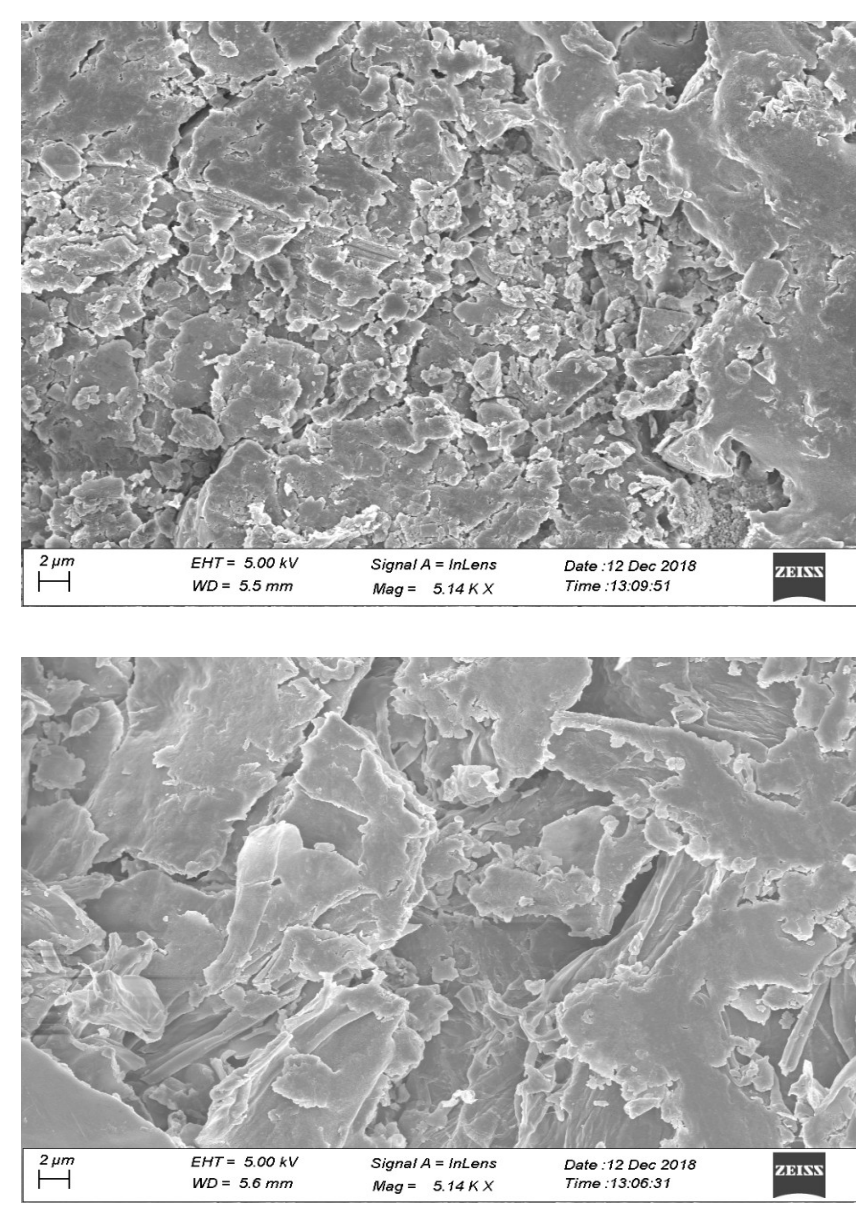

Fig. 5. SEM image of synthesized Ag-Nps.

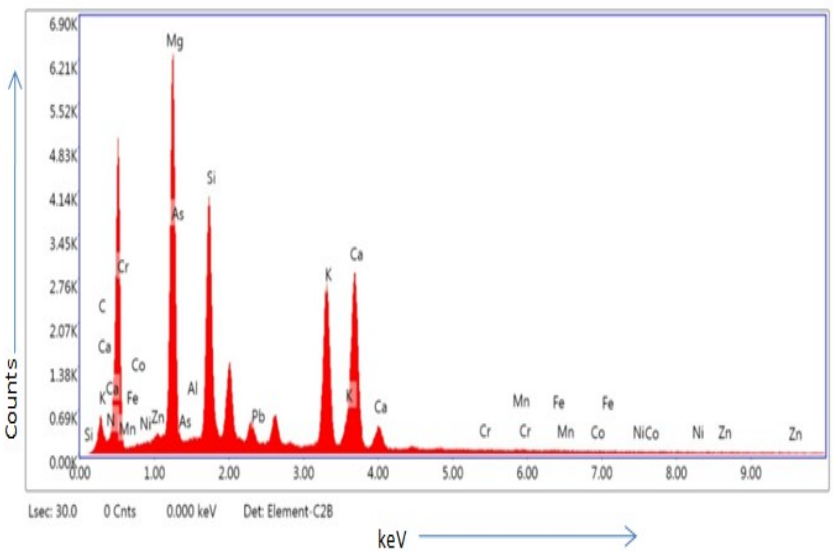

Fig. 6. SEM-EDAX of synthesized Ag-Nps.

however, comes from the artefact during sample preparation.

\section{Transmission Electron Microscopy}

Transmission Electron Microscopy technique was employed to estimate the shape and size of the synthesized Ag-NPs (Fig. 7 (a)). The Ag-NPs were irregular in shapes ranging from spherical to ovoid as well as rectangular with sizes ranging from 3 to 25 $\mathrm{nm}$ with $\sim 11 \mathrm{~nm}$ average size. The particles were predominantly spherical in shape. The calculation of the size of NPs was done based measurements carried out on different TEM images. It was visible that the edges of the particles were lighter than the centres, suggesting that the biomolecules aqueous 
Gynocardia odorata have capped the Ag-NPs and were stick on to their surfaces.

Selected Area Electron Diffraction (SAED) pattern of Ag-NPs was done to confirm Ag crystal formation (Fig. 7(b)). The polycrystallinity depicted in the diffraction rings may possibly because of the formation of small and single crystalline particles. A few of such particles came within the beam spot used for diffraction confirmed the crystal formation.
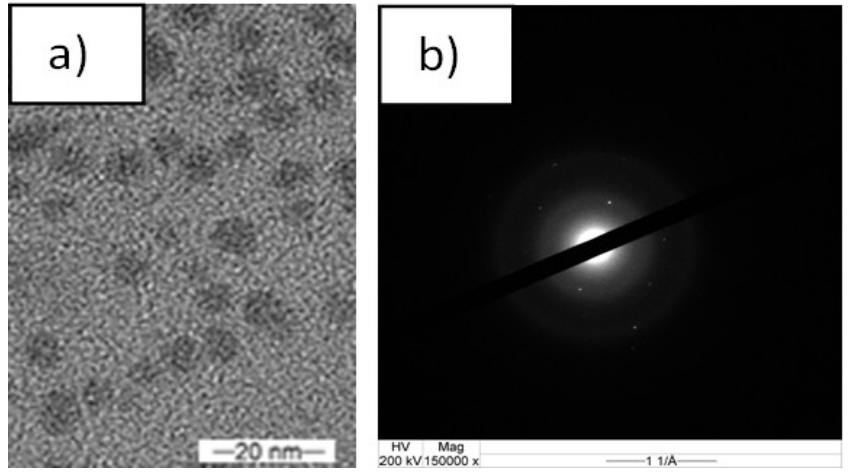

Fig. 7. (a) TEM image, and (b) SAED pattern of synthesized Ag-Nps.

\section{Antibacterial Studies}

For the antimicrobial studies, $24 \mathrm{hrs}$ of incubation with the Ag-NPs was carried out at $37{ }^{\circ} \mathrm{C}$ and the resulting zone of inhibition was measured (Fig. 8, Fig. 9). The Ag-NPs showed more activity as compared to the antibiotic and control. The zone of inhibition was found to be more or less same in the control group and $\mathrm{AgNO}_{3}$ as compared to the synthesized Ag-NPs. The zone of inhibition of the synthesized Ag-NPs (10\% $\left.\mathrm{GO}+\mathrm{AgNO}_{3}\right)$ was found to be highest in $\mathrm{E}$. coli $(16.00$ $\pm 0.50 \mathrm{~mm})$ and lowest against $S$. aureus $(12.83 \pm 1.53$ $\mathrm{mm}$ ) (Table 1). The data are presented in terms of triplicate (mean \pm SD) and is supported by the findings of previous workers (53-57).

Table 1. Antibacterial activity of the synthesized Ag-NPs

\begin{tabular}{clccc}
\hline \multirow{2}{*}{ Test organisms } & \multicolumn{2}{c}{ Diameter of growth of zone (mm) } \\
\cline { 2 - 5 } & Control & AgNO $_{3}$ & $\begin{array}{c}\mathbf{1 0 \%} \\
\mathbf{G O}+\mathbf{A g N O}_{3}\end{array}$ \\
\hline $\begin{array}{c}\text { (Gram } \\
\text { +ve })\end{array}$ & $\begin{array}{l}\text { Staphylococcus } \\
\text { aureus }\end{array}$ & $10.17 \pm 0.58$ & $10.50 \pm 1.00$ & $12.83 \pm 1.53$ \\
\cline { 2 - 5 } & Bacillus subtilis & $9.67 \pm 0.29$ & $12.50 \pm 0.50$ & $14.50 \pm 0.50$ \\
\hline $\begin{array}{c}\text { (Gram } \\
\text { ve })\end{array}$ & $\begin{array}{l}\text { Enterobacter } \\
\text { aerogenes }\end{array}$ & $10.17 \pm 0.58$ & $12.67 \pm 1.61$ & $14.33 \pm 0.76$ \\
\cline { 2 - 5 } & Escherichia coli & $10.33 \pm 0.29$ & $12.67 \pm 0.29$ & $16.00 \pm 0.50$ \\
\hline
\end{tabular}

\section{Conclusion}

In the present study, demonstration on an ecofriendly, rapid green chemical synthesis approach of Ag-NPs using Gynocardia odorata R. Br. has been reported. It provides a simple, low cost and efficient way for the synthesis of Ag-NPs utilizing the leaves of Gynocardia odorata which otherwise has no significant use. The results of this study demonstrate that the synthesis of Gynocardia odorata Silver nanoparticles is impacted by a range of experimental operational parameters. Different spectroscopic and
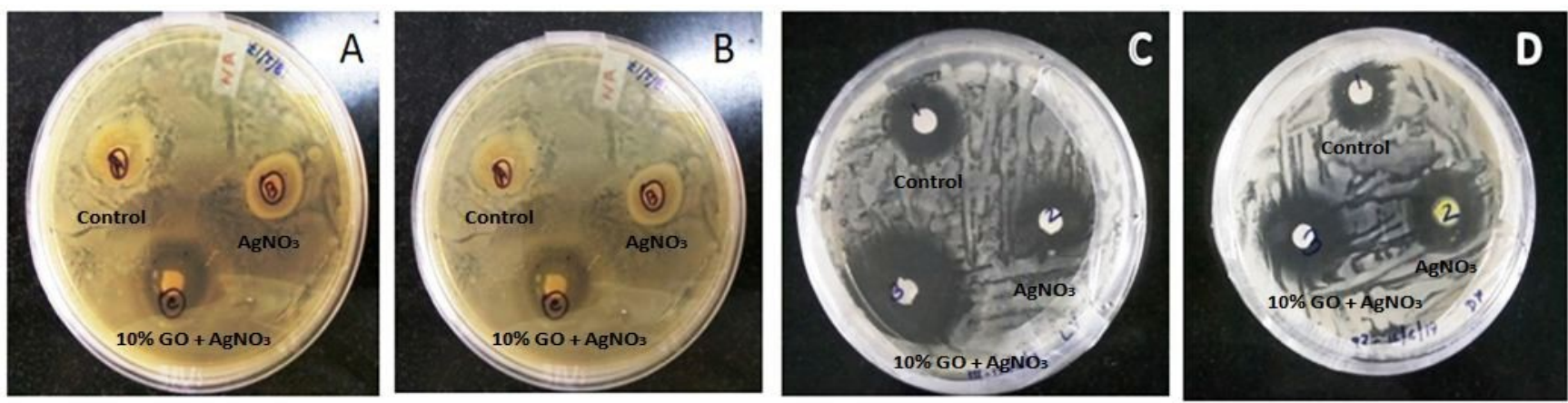

Fig. 8. Antibacterial activity of the synthesized Ag-NPs against test bacterial strains. (A, S. aureus, B. B. subtilis, C. E. coli, D. E. aerogenes).

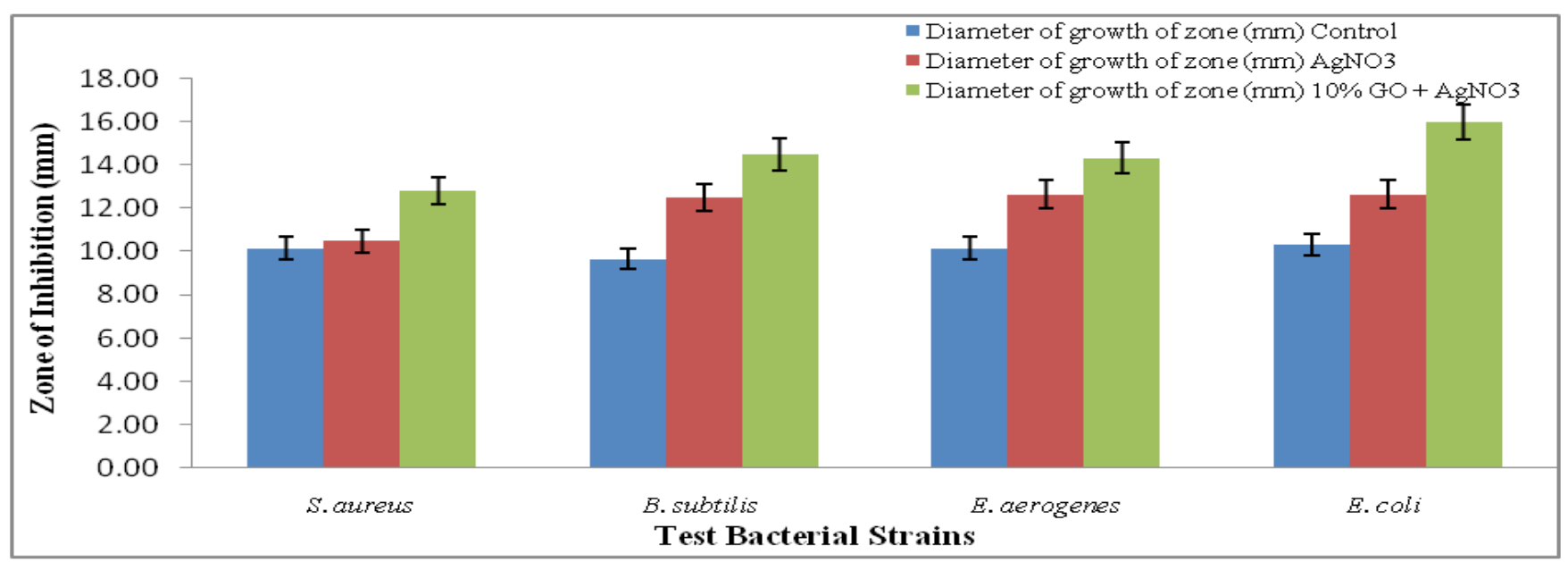

Fig. 9. Graphical representation of zone of inhabitation shown by the Ag-Nps. 
microscopic methods were used to characterize Gynocardia odorata Silver nanoparticles. The formation of Ag-NPs was first confirmed by a reddish brown colour change due to SPR peak in the UV-Vis spectrum observed in between 400-500 nm wavelengths. The resultant Ag-NPs was characterized using XRD, FTIR, SEM, EDX and TEM. FTIR spectrum confirmed the presence of Ag-NPs and their interactions with the functional biomolecules present in Gynocardia odorata leaf. The SEM confirmed the irregular shaped (spherical to ovoid as well as rectangular) nanoparticles whereas the TEM analyses revealed their sizes (sizes ranging from 3 to $25 \mathrm{~nm}$ with $\sim 11 \mathrm{~nm}$ average size). The EDX analysis verified the elemental composition of synthesized Ag-NPs with a strong Ag signal at $3.0 \mathrm{keV}$, whereas XRD analysis determined the crystallinity of Ag-NPs. The antimicrobial efficacy of synthesized Gynocardia odorata Ag-NPs compared favourably with the conventional antibiotic drug. As a result, our investigation revealed that the produced silver nanoparticles (Ag-NPs) are effective antimicrobial agents. The present study has opened up an innovative way for synthesizing antibacterial Ag-NPs using natural products which can be used in various biomedical applications. As the plant is commonly used in by different ethnic tribes for the treatment of different cutaneous disorders as well as tooth related issues (39); hence it can further be used for the treatment of other health related issues due to its antibacterial potential. Thus, in the domain of nanobiotechnology and nanomedicine it may be suggested as a product of value but to do this a thorough molecular characterization of the phytoconstituents is also necessitated.

\section{Acknowledgements}

The authors are thankful to the Department of Botany and Institutional Biotech Hub (IBH), Department of Biotechnology, Gauhati University; Centre of Excellence in Nanotechnology (CoEN), Assam Don Bosco University (Azara Campus) for providing facilities to carry out the present work. They also acknowledge Department of Chemistry, Gauhati University for the SEM-EDX analysis and National Science \& Technology Development Agency, Thailand for TEM analysis.

\section{Authors' contributions}

DK carried out the whole study except XRD and drafted the manuscript whereas HR carried out the XRD works under the supervision of ND, MCK and SB.

\section{Conflict of interests}

Authors do not have any conflict of interests to declare.

\section{References}

1. Kalita D, Baruah S. The impact of nanotechnology on food. In Nascimento RFd, Ferreira OP, Paula AJD, Neto VdOS.
Nanomaterials Applications for Environmental Matrices. Amsterdam. Elsevier Science. 2019; Pp.369-79. https://doi.org/10.1016/C2017-0-01930-4

2. Rastogi L, Arunachalam J. Sunlight based irradiation strategy for rapid green synthesis of highly stable silver nanoparticles using aqueous garlic (Allium sativum) extract and their antibacterial potential. Materials Chemistry and Physics. 2011;129:558-63.

https://doi.org/10.1016/j.matchemphys.2011.04.068

3. Klaus-Joerger T, Joerger R, Olsson E, Granqvist CG. Bacteria as workers in the living factory: metal-accumulating bacteria and their potential for Materials Science. Cambridge, USA. TRENDS in Biotechnology. 2001;19:15- 20. https://doi.org/10.1016/s01677799(00)01514-6

4. El-Rafie HM, El-Rafie MH, Zahran MK. Green synthesis of silver nanoparticles using polysaccharides extracted from marine macro algae. Carbohydrate Polymers. 2013;96:403-10. https://doi.org/10.1016/j.carbpol.2013.03.071

5. Blázquez ML, Castro L, Muñoz JA, González FG, Ballester A Mechanism and applications of metal nanoparticles prepared by Bio-Mediated process. Reviews in Advanced Sciences and Engineering. https://doi.org/10.1166/rase.2014.1064

2014;3:1-18

6. Gantar M, Patel V, Berthold D, Puranik P. Screening of cyanobacteria and microalgae for their ability to synthesize silver nanoparticles with antibacterial activity. Biotechnology Reports. 2014;56:1-8. https://doi.org/10.1016/j.btre.2014.12.001

7. Husen A, Siddiqi KS. Plants and microbes assisted selenium nanoparticles: characterization and application. Journal of Nanobiotechnology. 2014;12:28. https://doi.org/10.1186/s12951014-0028-6

8. Pantidos N, Horsfall LE. Biological synthesis of metallic nanoparticles by bacteria, fungi and plants. Journal of Nanomedicine and Nanotechnology. 2014;5(5):1-10. https://doi.org/10.4172/2157-7439.1000233

9. Jeffryes C, Agathos SN, Rorrer G. Biogenic nanomaterials from photosynthetic microorganisms. Current Opinion in Biotechnology. 2015;33:23-31. https://doi.org/10.1016/j.copbio.2014.10.005

10. Chopade BA, Wadhwani SA, Shedbalkar UU, Singh R. Biogenic selenium nanoparticles: Current status and future prospects: Applied Microbiology and Biotechnology; 2016. https://doi.org/10.1007/s00253-016-7300-7

11. Dahoumane SA, Yéprémian C, Djédiat C, Coute A, Fievet F, Coradin T, Brayner R. Improvement of kinetics, yield and colloidal stability of biogenic gold nanoparticles using living cells of Euglena gracilis microalga. Journal of Nanoparticle Research. 2016;18:79.

12. Husen A, Siddiqi KS. Fabrication of metal nanoparticles from fungi and metal salts: scope and application. Nanoscale Research Letters. 2016;11:98. https://doi.org/10.1007/s11051016-3378-1

13. Mohanasrinivasan V, Selvarajan E. Biosynthesis and characterization of ZnO nanoparticles using Lactobacillus plantarum VITES07. Materials Letters. 2013;112:180-92. https://doi.org/10.1016/j.matlet.2013.09.020

14. Gardea-Torresdey JL, Parsons JG, Gomez E, Peralta-Videa J, Troiani HE, Yacaman JM. Formation and growth of $\mathrm{Au}$ nanoparticles inside live Alfalfa plants. Nano Letters. 2002; 2(4):397- 401. https://doi.org/10.1021/nl015673+

15. Gardea-Torresdey JL, Gomez E, Peralta-Videa JR, Parsons JG Troiani H, Jose-Yacaman M. Alfalfa Sprouts: A natural source for the synthesis of silver nanoparticles. Langmuir. 2003;19:1357-61. https://doi.org/10.1021/la020835i

16. Darroudi M, Ahmad MB, Abdullah AH, Ibrahim NA. Green synthesis and characterization of gelatin-based and sugarreduced silver nanoparticles. International Journal of Nanomedicine. https://doi.org/10.2147/IJN.S16867

2011;6:569-74

17. Yun Y-S, Sathishkumar M, Sneha K, Won SW, Cho C-W, Kim S. Cinnamon zeylanicum bark extract and powder mediated green synthesis of nano-crystalline silver particles and its bactericidal activity. Colloids and Surfaces B: Biointerfaces. 2009;73:332-38. https://doi.org/10.1016/j.colsurfb.2009.06.005 
18. Dada AO, Adekola FA, Adeyemi OS, Bello MO, Adetunji CO, Awakan OJ, Femi-Adepoju GA. Exploring the Effect of Operational Factors and Characterization Imperative to the Synthesis of Silver Nanoparticles. In: Silver Nanoparticles Fabrication, Characterization and Applications; 2018a. https://doi.org/10.5772/intechopen.76947

19. Dada AO, Inyinbor AA, Idu IE, Bello OM, Oluyori AP, AdelaniAkande TA, Okunola AA, Dada O. Effect of operational parameters, characterization and antibacterial studies of green synthesis of Silver Nanoparticles, using Tithonia diversifolia. Peer $\mathrm{J}$ - the Journal of Life and Environmental Sciences. 2018;e5865. https://doi.org/10.7717/peerj.5865

20. Dada AO, Femi-Adepoju AG, Otun KO, Adepoju AO, Fatoba OP. Green synthesis of silver nanoparticles using terrestrial fern (Gleichenia pectinata (Willd.) C. Presl.): characterization and antimicrobial studies. Heliyon. 2019;5:e01543. https://doi.org/10.1016/j.heliyon.2019.e01543

21. Parak WJ, Gerion D, Pellegrino T, Zanchet, D, Micheel C, Williams SC, Boudreau R, Gros MAL, Larabell CA, Alivisatos AP. Biological applications of colloidal nanocrystals. Nanotechnology. 2003;14:R15-R27. https://doi.org/10.1088/0957$4484 / 14 / 7 / 201$

22. Nam JM, Thaxton CS, Mirkin CA. Nanoparticle-Based Bio-Bar Codes for the Ultrasensitive Detection of Proteins. Science. 2003;301:1884-86. https://doi.org/10.1126/science.1088755

23. Mandal D, Bolander ME, Mukhopadhyay D, Sarkar G, Mukherjee P. The use of microorganisms for the formation of metal nanoparticles and their application. Applied Microbiology and Biotechnology. 2006;69:485-92. https://doi.org/10.1007/s00253-005-0179-3

24. Sastry M, Mukherjee P, Ahmad A, Mandal D, Senapati S, Sainkar SR, Khan MI, Parishcha R, Ajaykumar PV, Alam M, Kumar R. Fungus-mediated synthesis of silver nanoparticles and their immobilization in the mycelial matrix: A novel biological approach to nanoparticle synthesis. Nano Letters. 2001;1(10):515-19. https://doi.org/10.1021/nl0155274

25. Paknikar KM, Kowshik M, Ashtaputre S, Kharrazi S, Vogel W Urban J, Kulkarni SK. Extracellular synthesis of silver nanoparticles by a silver-tolerant yeast strain MKY3. Nanotechnology. 2003;14:95-100. https://doi.org/10.1088/0957$4484 / 14 / 1 / 321$

26. Lee JY, Xie J, Wang DIC. Silver Nanoplates: from Biological to biomimetic synthesis. ACS Nano. 2007;1(5):429-39. https://doi.org/10.1021/nn7000883

27. Misra A, Bar H, Bhui DK, Sahoo GP, Sarkar P, Pyne S. Green synthesis of silver nanoparticles using seed extract of Jatropha curcas. Colloids and Surfaces A: Physicochemical and Engineering Aspects. 2009;348:212- 216 https://doi.org/10.1016/j.colsurfa.2009.07.021

28. Ahmad MA, Darroudi M, Abdullah AH, Ibrahim NA, Shameli K. Effect of accelerator in green synthesis of silver nanoparticles. International Journal of Molecular Sciences. 2010;11:38983905. https://doi.org/10.3390/ijms11103898

29. Kandasamy K, Nabikhan A, Raj A, Alikunhi NM. Synthesis of antimicrobial silver nanoparticles by callus and leaf extracts from saltmarsh plant, Sesuvium portulacastrum L. Colloids and Surfaces B: Biointerfaces. 2010;79:488-93. https://doi.org/10.1016/j.colsurfb.2010.05.018

30. Sharma S, Ahmad N, Alam MK, Singh VN, Shamsi SF, Mehta BR, Fatma A. Rapid synthesis of silver nanoparticles using dried medicinal plant of basil. Colloids and Surfaces B: Biointerfaces. 2010;81:81-86. https://doi.org/10.1016/j.colsurfb.2010.06.029

31. Zinjarde S, Bankar A, Joshi B, Kumar AR. Banana peel extract mediated novel route for the synthesis of silver nanoparticles. Colloids and Surfaces A: Physicochemical and Engineering Aspects.

https://doi.org/10.1016/j.colsurfa.2010.07.024

2010;368:58-63.

32. Harris AT, Lukman AI, Gong B, Marjo CE, Roessner U. Facile synthesis, stabilization, and anti-bacterial performance of discrete Ag nanoparticles using Medicago sativa seed exudates. Journal of Colloid and Interface Science. 2011;353:433-44. https://doi.org/10.1016/j.jcis.2010.09.088
33. Iravani S. Green synthesis of metal nanoparticles using plants. Green Chemistry. https://doi.org/10.1039/C1GC15386B

2011;13:2638-2650.

34. Thajuddin N, MubarakAli, D, Jeganathan K, Gunasekaran M. Plant extract mediated synthesis of silver and gold nanoparticles and its antibacterial activity against clinically isolated pathogens. Colloids and Surfaces B: Biointerfaces. 2011;85:360-65. https://doi.org/10.1016/j.colsurfb.2011.03.009

35. Lemke DE. A Synopsis of Flacourtiaceae. Aliso: A Journal of Systematic and Evolutionary Botany. 1988;12(5):32. https://doi.org/10.5642/aliso.19881201.05

36. APG II. An update of the Angiosperm Phylogeny Group classification for the orders and families of flowering plants: APG II. Botanical Journal of the Linnean Society. 2003;141:399 436. https://doi.org/10.1046/j.1095-8339.2003.t01-1-00158.x

37. APG III. An update of the Angiosperm Phylogeny Group Classification for the orders and families of flowering plants: APG III. Botanical Journal of the Linnaean Society. 2009;161(2):105-21. 8339.2009.00996.x

38. Kanjilal UN, Kanjilal PC, Das A. Flora of Assam. Omsons Publications. 1934;1(1):84- 94.

39. Sharma N, Yadav AK, Saha D, Das T, Hazarika B. Evaluation of the Leaves of the $G$. odorata Plant for Antibacterial Activity. Scholars Academic Journal of Pharmacy. 2016;5(5):123-27. https://doi.org/10.9734/sajrm/2019/v5i330132

40. Rymbai H, Roy AR, Deshmukh NA, Jha AK, Shimray W, War GF, Ngachan SV. Analysis study on potential underutilized edible fruit genetic resources of the foothills track of Eastern Himalayas, India. Genetic Resources and Crop Evolution. 2016;63:125-39. https://doi.org/10.1007/s10722-015-0342-3

41. Khan MA, Bera S, Spicer TEV, Spicer RA. Occurrence of Gynocardia odorata Robert Brown (Achariaceae, formerly Flacourtiaceae) from the Plio-Pleistocene sediments of Arunachal Pradesh, Northeast India and its palaeoclimatic and phytogeographic significance. Review of Palaeobotany and Palynology.

https://doi.org/10.1016/j.revpalbo.2014.10.002

2014;211:1-9.

42. Khan M, Al-Marri AH, Khan M, Shaik MR, Mohri N, Adil SF, Kuniyil M, Alkhathlan HZ, Al-Warthan A, Tremel W, Tahir MN, Siddiqui MRH. Green approach for the effective reduction of graphene oxide using Salvadora persica L. root (Miswak) extract. Nanoscale Research Letters. 2015;10:281. https://doi.org/10.1186/s11671-015-0987-z

43. Rana TS, Ranade SA. The enigma of monotypic taxa and their taxonomic implications. Current Science. 2009; 2(96): 219-29.

44. Tag H, Das AK. Ethnobotanical notes on the Hill Miri tribe of Arunachal Pradesh. Indian Journal of Traditional Knowledge. 2004;3(1):80-85.

http://nopr.niscair.res.in/handle/123456789/9339

45. Chhetri DR. Medicinal plants used as antipyretic agent by the traditional herbs of Darjeling Himalayas. Indian Journal of Traditional Knowledge. http://nopr.niscair.res.in/handle/123456789/9361

46. Tag H, Das AK, Kalita P. Diversity and Traditional Uses of Some Poisonous Plants of Arunachal Pradesh. Indian Journal of Traditional Knowledge. 2005;4(1):57- 64.

47. Rai PK, Lalramnghinglova H. Ethnomedicinal Plant Resources of Mizoram. India: Implication of Traditional Knowledge in Health Care System. Ethnobotanical Leaflets. 2010;14:274-305.

48. Tag H, Kalita BC, Gogoi BJ, Hui PK. Diversity and Traditional Uses of Some Poisonous Plants of Arunachal Pradesh. International Journal of Advance Research and Innovative Ideas in Education. 2017;3(1):755-63.

49. Parascandola J. Chaulmoogra oil and the treatment of leprosy. Pharmacy in History, Madison. 2003;45(2):47-57.

50. Ali M. Pharmacognosy- Pharmacognosy and Phytochemistry. CBS publishers and distributors. 2008;1:411- 412 . 
51. Gupta N, Khan H, Mohammed MS, Agarwal M, Khan G, Mohan G. Antiulcer activity of seed extracts of Gynocardia odorata Roxb. on pylorus ligation and indomethacin induced gastric lesions in albino rats. International Journal of Development Research. 2013;3(5):49-54.

52. Seal T. Evaluation of some wild edible plants from nutritional aspect used as vegetable in Meghalaya state of India. World Applied Sciences Journal. 2011;12(8):1282-87.

53. Jain D, Daima HK, Kachhwaha S, Kothari SL. Synthesis of plantmediated silver nanoparticles using papaya fruit extract and evaluation of their anti-microbial activities. Digest Journal of Nanomaterials and Biostructures. 2009;4(3):557-63.

54. Sharma KV, Yngard RA, Lin Y. Silver nanoparticles: green synthesis and their antimicrobial activities. Advances in Colloid and Interface Science. 2009;145(1-2):83-96. https://doi.org/10.1016/j.cis.2008.09.002

55. Sathishkumar M, Sneha K, Won SW, Cho CW, Kim S, Yun YS. Cinnamomum zeylanicum bark extract and powder mediated green synthesis of nano-crystalline silver particles and its bactericidal activity. Colloids Surfaces B. Biointerfaces. 2009;73:332-38. https://doi.org/10.1016/j.colsurfb.2009.06.005

56. Singh RP. Biosynthesis of silver nanoparticles using Ocimum sanctum (Tulsi) leaf extract and screening its antimicrobial activity. Journal of Nanoparticle Research. 2011;13:2981-88. https://doi.org/10.1007/s11051-010-0193-y
57. Wani IA, Khatoon S, Ganguly A, Ahmed J, Ahmad T. Structural characterization and antimicrobial properties of silver nanoparticles prepared by inverse micro emulsion method. Colloids Surfaces B Biointerfaces. 2013;243-50. https://doi.org/10.1016/j.colsurfb.2012.07.001

\section{Additional information}

Peer review information: Plant Science Today thanks Sectional Editor and the other anonymous reviewers for their contribution to the peer review of this work.

Reprints and permissions information is available at

https://horizonepublishing.com/journals/index.php/PST/open_access_policy

Publisher's Note: Horizon e-Publishing Group remains neutral with regard to jurisdictional claims in published maps and institutional affiliations.

To cite this article: Kalita D, Rajbongshi H, Devi N, Mohan Chandra Kalita MC, Baruah S. Biosynthesis and characterization of Gynocardia odorata R. Br. mediated silver nanoparticles and evaluation of its antimicrobial activity. Plant Science Today. 2021;8(4):754-761. https://doi.org/10.14719/pst.2021.8.4.1217

Plant Science Today, published by Horizon e-Publishing Group, is covered by Scopus, Web of Science, BIOSIS Previews, Clarivate Analytics, etc. See https://horizonepublishing.com/journals/index.php/PST/indexing_abstracting 